\title{
BISNIS DROPSHIP DALAM TINJAUAN FIKIH MUAMALAH
}

\section{Rizki Syahputra}

Dosen Tetap Sekolah Tinggi Ilmu Ekonomi Labuhanbatu

\section{A. Pendahuluan}

Perkembangan internet memberi pengaruh dalam aspek kehidupan manusia pada zaman sekarang. Internet memberi kemudahan berinteraksi, berkomunikasi dengan cepat. Salah satu manfaat keberadaan internet adalah sebagai media dalam memberi informasi produk. Penggunaan internet tidak hanya pada pemanfaatan informasi dapat juga digunakan sebagai sarana untuk melakukan transaksi bisnis.

Salah satu praktik bisnis ialah dengan menggunakan sistem Dropship. Bisnis dropship kini menimbulkan banyak perdebatan dalam hukum Islam mengenai halal dan haramnya. Model tersebut Jual beli Dropship merupakan teknik pemasaran melalui media internet dimana seorang dropshipper tidak harus membeli barang atau harus mempunyai modal. Dalam praktiknya dropshiper hanya bermodalkan foto dari supplier atau toko tanpa harus menyetok barang, kemudian menjualnya ke pelanggan dengan harga yang ditentukan oleh dropshiper. Dropship menjadi salah satu alternatif yang dipilih oleh beberapa kalangan masyarakat untuk melakukan sistem jual beli online. Disinilah, sebagai seorang Muslim dituntut untuk mengetahui Hukum bisnis Dropship sesuai Syariat, bisnis prinsip syariah bukan saja berkenaan dengan untung dan rugi tapi surga dan neraka

\section{B. Landasan Teori}

Bisnis adalah pertukaran barang, jasa, atau uang yang saling mneguntungkan atau memberi manfaat. Menurut arti dasarnya, bisnis memilili makna sebagai "the buying and selling of goods and service." Kerangkan bisnis islami adalah aktivitas yang dilandasi oleh saling ridha dan rahmat antara penjual dan pembeli,dalam sebuah aktivitas di dalam sebuah pasar, baik pasar kongkret maupun abstrak.

Dropshipping adalah sistem jual beli yang memungkinkan penjual (dropshipper) menjual barang secara lansung dari supplier tanpa harus membeli atau mengadakan stok terlebih dahulu. Sedangkan penjual (dropshipper) adalah agen yang menjual produk supplier dengan tidak memiliki priduk supplier, jadi penjual (dropshipper) hanyalah agen yang menjual informasi produk. Skema transaksi sistem dropship bisa dicontohkan sebagai

berikut. Si A adalah seorang dropshipper. Dia menjadi seorang dropshipper dari grosir/supplier B. Setelah terjadi kesepakatan antara A dan B, A mulai melakukan promosi sesuai cara yang efektif menurutnya. Saat ada pemesanan dan pembelian yang diterima oleh A, A meminta konsumen untuk membayar uang dengan jumlah yang telah ditentukan. 
Setelah pembayaran diterima, order tersebut diteruskan kepada B, kemudian mentransfer uang yang ditentukan kepada B. Setelah pembayaran diterima B, ia akan mengurus sisanya, mulai dari packing hingga pengiriman ke alamat konsumen.

Bisnis dropship adalah sebuah sistem penjualan sebuah produk secara online di mana penjual/pengecer (dropshipper) tidak harus memiliki modal besar atau produk sendiri. Sistem dropship berbeda dengan sistem reseller yang mengharuskan penjual/pengecer untuk membeli produk kepada supplier/pemilik barang untuk stok lalu dijual ke konsumen dengan mengambil keuntungan dari selisih harga barang.

Istilah fikih muamalah terdiri dari dua kata, fikih dan muamalah. Arti fikih secara bahasa adalah paham, sedangkan secara istilah pengetahuan tentang hukum syariat yang berkaitan dengan perbuatan manusia yang di ambil dari dalil-dalil yang terperinci. Adapun muamalah secara gamblang bermakna hubungan antar manusia, jadi dapat kita simpulkan bahwa fikih muamalah adalah pengetahuan tentang hukum syariat yang mengatur hubungan individu dengan individu lainnya.

\section{Pembahasan}

Dalam hukum jual-beli, tidak ada syarat yang melarang seseorang menjual barang milik orang lain. Jadi prinsipnya, seorang boleh menjual barang milik orang lain, asalkan seizin dari yang punya. Ada dua cara dalam masalah jual beli ini :Cara Pertama : Simsarah, Cara ini disebut simsarah, yaitu seeorang menjualkan barang milik orang lain dan dia mendapat fee atas jasa menjualkannya. Akad yang pertama ini disepakati kehalalnya oleh seluruh ulama.

Lalu bagaimana dengan hadits berikut ini yang melarang kita menjual sesuatu yang tidak ada pada diri kita?

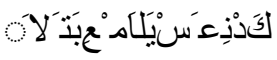

Janganlah kamu menjual barang yang tidak kamu miliki (HR. Tirmizy)

Hadits ini melarang seseorang menjual barang yang bukan miliknya, maksudnya seseorang menjual barang yang memang dia tidak bisa mengadakannya atau menghadirkannya.

Misalnya, jual ikan tertentu yang masih ada di tengah lautan lepas. sehingga hukumnya haram.

Selain itu para ulama juga menyebutkan bahwa maksud larangan dalam hadits ini adalah seseorang menjual barang milik orang lain tanpa SEIZIN dari yang empunya. 
Cara Kedua : Akad Salam (Salaf) Cara kedua disebut dengan jual-beli salam, atau akad salam. Terkadan juga disebut dengan akad salaf. Keduanya bermakna sama. Bentuknya merupakan kebalikan dari jual-beli hutang atau kredit. Dalam jual-beli secara hutang atau kredit, barangnya diberikan duluan tetapi uangnya masih dihutang, alias dicicil. Dasarnya adalah hadits-hadits berikut ini :

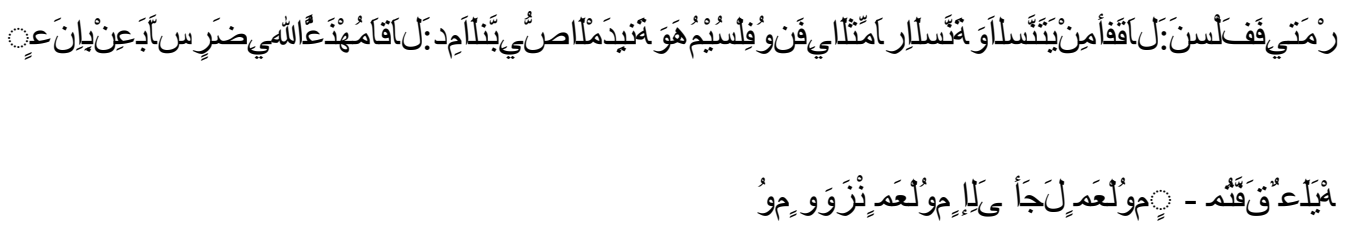

Ibnu Abbas RA berkata bahwa ketika Nabi SAW baru tiba di Madinah, orang-orang madinah biasa menjual buah kurma dengan cara salaf satu tahun dan dua tahun. Maka Nabi SAW bersabda,"Siapa menjual buah kurma dengan cara salaf, maka lakukanlah salaf itu dengan timbangan yang tertentu, berat tertentu dan sampai pada masa yang tertentu". (HR. Bukhari dan Muslim)

Dari dua cara akad di atas, maka jual beli dropship ini tidak melanggar ketentuan syariah. Meski kita sebagai penjual belum punya barangnya, dan modal kita cuma spek saja, tetapi syariat Islam membolehkan akad seperti ini. Akadnya bisa saja sebagai simsarah, atau broker. Mungkin yang agak mendekati adalah reseller. Berarti kita tidak membeli barang atau jasa, kita hanya membantu menjualkan barang atau jasa orang lain. Lalu kita mendapat fee dari tiap penjualan.

Atau akadnya bisa juga pakai akad kedua, yaitu akad salam. Pembeli membayar dulu kepada kita atas suatu barang atau jasa yang belum kita serahkan, bahkan belum kita miliki. Lalu uang pembayarannya itu baru kita belikan barang yang dimaksud, dan kita jualkan kepada si pembeli, dimana kita mendapatkan selisih harganya..

Hanya saja dalam akad salam ini, harus dipenuhi beberapa syarat dan ketentuan, antara lain :

\section{Bukan Ain-nya Tapi Spesifikasinya}

Dalam akad salam, penjual tidak menjual ain suatu barang tertentu yang sudah ditetapkan, melainkan yang dijual adalah barang dengan spesifikasi tertentu.

2. Barang Jelas Spesifikasinya 
Barang yang dipesan harus dijelaskan spesifikasinya, baik kualitas mau pun juga kuantitas. Termasuk misalnya jenis, macam, warna, ukuran, dan spesifikasi lain. Pendeknya, setiap kriteria yang diinginkan harus ditetapkan dan dipahami oleh kedua-belah pihak, seakan-akan barang yang dimaksud ada di hadapan mereka berdua.

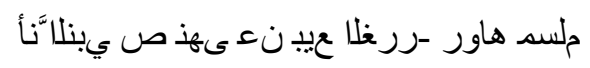

Nabi SAW jual-beli untung-untungan." (HR Muslim)

\section{Barang Tidak Diserahkan Saat Akad}

Apabila barang itu diserahkan tunai, maka tujuan utama dari salam malah tidak tercapai, yaitu untuk memberikan keleluasan kepada penjual untuk bekerja mendapatkan barang itu dalam tempo waktu tertentu.

Dalilnya adalah sabda Rasulullah SAW :

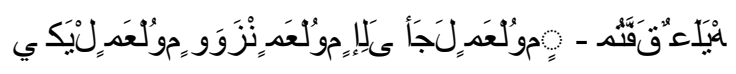

Siapa yang meminjamkan buah kurma maka harus meminjamkan dengan timbangan yang tertentu dan sampai pada masa yang tertentu”. (HR. Bukhari dan Muslim)

Al-Qadhi Ibnu Abdil Wahhab mengatakan bahwa salam itu adalah salaf, dimana akad itu memang sejak awal ditetapkan untuk pembayaran di awal dengan penyerahan barang belakangan.

4. Batas Minimal Penyerahan Barang

Al-Karkhi dari Al-Hanafiyah menyebutkan minimal jatuh tempo yang disepakati adalah setengah hari dan tidak boleh kurang dari itu.

Ibnu Abil Hakam mengatakan tidak mengapa bila jaraknya 1 hari.

Ibnu Wahab meriwayatkan dari Malik bahwa minimal jarak penyerahan barang adalah 2 atau 3 hari sejak akad dilakukan. 
Ulama lain menyebutkan minimal batasnya adalah 3 hari, sebagai qiyas dari hukum khiyar syarat.

\section{Jelas Waktu Penyerahannya}

Harus ditetapkan di saat akad dilakukan tentang waktu (jatuh tempo) penyerahan barang. Hal ini berdasarkan sabda Rasulullah SAW :

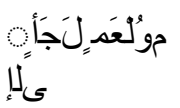

Hingga waktu (jatuh tempo) yang telah diketahui (oleh kedua belah pihak)

pula." (Muttafaqun 'alaih)

Para fuqaha sepakat bila dalam suatu akad salam tidak ditetapkan waktu jatuh temponya, maka akad itu batal dan tidak sah.Jatuh tempo bisa ditetapkan dengan tanggal, bulan, atau tahun tertentu, atau dengan jumlah hari atau minggu atau bulan terhitung sejak disepakatinya akad salam itu.

\section{Dimungkinkan Untuk Diserahkan Pada Saatnya}

Pada saat menjalankan akad salam, kedua belah pihak diwajibkan untuk memperhitungkan ketersedian barang pada saat jatuh tempo. Persyaratan ini demi menghindarkan akad salam dari praktek tipu-menipu dan untung-untungan, yang keduanya nyata-nayata diharamkan dalam syari'at Islam.

7. Jelas Tempat Penyerahannya

Yang dimaksud dengan barang yang terjamin adalah barang yang dipesan tidak ditentukan selain kriterianya. Adapun pengadaannya, maka diserahkan sepenuhnya kepada pengusaha, sehingga ia memiliki kebebasan dalam hal tersebut. Pengusaha berhak untuk mendatangkan barang dari ladang atau persedian yang telah ada, atau dengan membelinya dari orang lain. 
Secara ringkas mengenai tinjauan fikih muamalah sebagaimana juga diterangkan oleh Oni Sahroni pakar ekonomi Islam Indonesia, bahwa bisnis dropship diperbolehkan dengan memenuhi beberapa syarat:

Pertama, produk yang dijual itu halal dan diketahui dengan jelas. Begitu pula penjual, baik dropshiper maupun supplier, harus menjelaskan objek jual beserta harganya agar tidak termasuk produk yang gharar (tidak jelas) yang dilarang dalam Islam. Hal tersebut sesuai dengan hadits Rasulullah SAW,

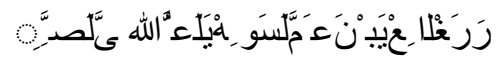

Artinya: "Rasulullah SAW melarang jual beli yang mengandung gharar." (HR. Muslim)

Kedua, memenuhi unsur ijab qabul (shigat) yang menunjukkan keinginan jual beli dan ridha kedua belah pihak. Menurut madzhab Syafiiyah, bisnis dropship ini bisa melahirkan perpindahan kepemilikan dengan sekedar akad atau transaksi yang disepakati, sesuai dengan pendapat ulama, : "Pembeli memiliki barang dan penjual memiliki harga barang dengan sekadar akad jual beli yang sah dan tanpa menunggu adanya serah terima (taqabudh)."

Ketiga, akad antara dropshipper dan pemesan adalah jual beli tidak tunai, seperti halnya antara reseller dan pembeli. Sedangkan, akad antara dropshipper dan supplier merupakan akad ijarah, yaitu dropshipper mendapatkan imbalan atas jasa pemasaran atau mendapatkan pembeli. Skema ijarah tersebut sesuai dengan fatwa DSN MUI No. 09/DSN-MUI/IV/2000 tentang Ijarah.

Imbalan yang diterima oleh dropshipper/reseller ini bisa berbentuk nominal tertentu atau persentase yang telah disepakati antara produsen dan dropshipper. Contoh untuk imbalan dalam bentuk nominal adalah jika dropshipper bisa menjual satu produk baju, misalnya, dia berhak mendapatkan imbalan. Sedangkan untuk imbalan dalam bentuk persentase jika dropshipper bisa menjual satu produk baju, misalnya, dia berhak mendapatkan persentase sekian persen dari harga jual selama jelas diketahui. Sebagaimana hadis riwayat 'Abd arRazzaq dari Abu Hurairah dan Abu Sa'id al-Khudri, Nabi SAW bersabda,

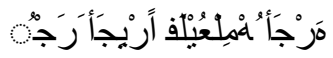

Artinya: "Barangsiapa mempekerjakan pekerja, beritahukanlah upahnya." (HR. 'Abd arRazzaq) 


\section{Kesimpulan}

Dengan demikian, bisnis dropship dalm tinjauan fikih Muamalah itu dibolehkan dengan dua cara yaitu dengan cara simsarah dan salam dengan syarat yang harus dipenuhi atau dibolehkan dengan syarat produknya halal dan jelas, serah terima melahirkan perpindahan kepemilikan, dan memenuhi skema jual beli tidak tunai dan skema ijarah.

\section{Daftar Bacaan}

Juhratul khulwah, 2013. Tinjauan Hukum Islam Terhadap Sistem Jual Beli Dropship, Yogyakarta: Sunan Kalijaga.

Mhd. Ma'sum billah, Islamic. 2010. E-Ecommerce Terapan, Tinjauan Hukum Dan Praktis,ter.Ahmad Dumyathi Bashori (Malaysia : Sweet and Maxwell asia

Nazar Bakti, 2003, Fiqh dan Ushul Fiqh, Jakarta: PT.Raja Grafindo

Rachmat Syefe'i, 2001, Fiqh Muamalah, Bandung: CV. Pustaka Setia

\section{www.rumahwasathia.org}

\section{www.rumahfiqih.com}

